\title{
A COMPARATIVE STUDY ON 2-(2-BENZYLIDENEHYDRAZINYL)-4-(3-METHYL-3- PHENYLCYCLOBUTYL) THIAZOLE : X-RAY, HF AND DFT STUDIES
}

\author{
Buse Ferah ${ }^{1, *}$, Ibrahim Yilmaz ${ }^{2}$, Muharrem Dinçer ${ }^{1}$, Alaaddin Çukurovali ${ }^{3}$ \\ ${ }^{1}$ Department of Physics, Faculty of Arts and Sciences, Ondokuz Mayis University, 55139- Kurupelit, Samsun, Turkey \\ ${ }^{2}$ Department of Chemistry, Faculty of Science, University of Karamanoğlu Mehmet Bey, 70200 Karaman, Turkey \\ ${ }^{3}$ Department of Chemistry, Faculty of Sciences, Firat University, 23200 Elazı $\breve{g}$, Turkey.
}

\begin{abstract}
The title compound, 2-(2-benzylidenehydrazinyl)-4-(3-methyl-3-phenylcyclobutyl)thiazole $\left(\mathrm{C}_{21} \mathrm{H}_{21} \mathrm{~N}_{3} \mathrm{~S}\right)$ was prepared and characterized by $\mathrm{X}$ - ray single crystal diffraction and IR and NMR spectroscopies. The compound crystallizes in the triclinic space group P $\overline{1}$ with $\mathrm{a}=5.8973(4) \AA, \mathrm{b}=10.4727(18) \AA, \mathrm{c}=15.136(2) \AA, \alpha=86.505(13)^{\circ}, \beta=84.242(12)^{\circ}, \gamma=$ $89.870(13)^{\circ}$ and $\mathrm{Z}=2$. The molecular geometry was optimized using Hartree-Fock and Density Functional Theory (DFT) (B3LYP) method with the 6-31G(d) basis set. Molecular electrostatic potentiel (MEP) and frontier molecular orbitals (FMO) were calculated by the HF/6-31G(d) method.
\end{abstract}

Keywords: Cyclobutane, X-Ray diffraction, Molecular modeling (MM), Hartree-fock (HF), Density functional theory (DFT)

\section{2-(2-BENZILIDEN HIDRAZINIIL)-4-(3-METIL-3-FENILSİKLOBÜTIL) TIYAZOL BİLEŞIĞGiNIN X-IŞINI, HF VE DFT ÇALIŞMALARI ÜZERINE KIYASLAMASI}

ÖZET

Bileşiğimiz 2-(2- benziliden hidrazinil)-4-(3- metil-3-fenilsiklobütil) tiyazol $\left(\mathrm{C}_{21} \mathrm{H}_{21} \mathrm{~N}_{3} \mathrm{~S}\right)$ hazırlandı ve X-1şını tek kristal kırınımı IR ve NMR spektroskopileri ile karakterize edildi. Bileşiğimiz triklinik kristal sisteme sahip olup P $\overline{1}$ uzay grubuna sahip olan kristalin parametreleri $\mathrm{a}=5.8973(4) \AA, \mathrm{b}=10.4727(18) \AA, \mathrm{c}=15.136(2) \AA, \alpha=86.505(13)^{\circ}, \beta=84.242(12)^{\circ}, \gamma=$ $89.870(13)^{\circ}$ ve $Z=2$. Moleküler geometri $6-31 G(d)$ baz seti ile Hartree-Fock ve Yoğunluk Fonksiyoneli Teorisi (DFT) (B3LYP) metodları kullanılarak optimize edildi. Moleküler elektrostatik potensiyel (MEP) ve sınır moleküler orbitaller (FMO) HF/6-31G(d) metodu ile hesapland1.

Anahtar Kelimeler: Siklobütan, X-1şını kırınımı, Moleküler modelleme (MM), Hartree-fock (HF), Yoğunluk fonksiyoneli teorisi (DFT)

\section{INTRODUCTION}

It is well know that 3-substituted cyclobutane carboxylic acid derivatives exhibit anti-inflammatory and antidepressant activities [1] as well as liquid crystal properties [2]. As a consequence of the unique three-dimensional disposition of substituents and torsional ring strain driven high reactivity, cyclobutanes have received considerable attention by medicinal and synthetic chemists as drugscaffolds and/or synthetic intermediates in routes targeted at medicinally useful substances $[3,4]$. The chemistry of aminothiazoles and their derivatives has attracted the attention of chemists, because they exhibit important biological activity in medicinal chemistry [5]. Thiazole derivatives exhibit different pharmaceutical properties such as anticancer [6, 7], anticonvulsant [8], antipsychoticlike [9], antibacterial, antifungal [10, 11], antitubercular [12], antimicrobial [13], analgesic and antiinflammatory [14] activities.

Investigations into the structural stability of these compounds using both experimental techniques and theoretical methods have been of interest for many years [15]. Various computational techniques are

*Corresponding Author: buseferah@ gmail.com 
improved and so calculations are correctly concluded. Hartree-Fock (HF) and Density Functional Theory (DFT) methods have been the most commonly used for computation in theoretical modeling. HF and DFT methods calculated a great variety of molecular properties: molecular structures, vibrational frequencies, chemical shifts, molecular electrostatic potential, frontier molecular orbitals and Mulliken atomic charges, etc..

In this study, 2-(2-benzylidenehydrazinyl)-4-(3-methyl-3-phenylcyclobutyl)thiazole has been investigated both experimentally and theoretically. The title molecule was described and characterized by ${ }^{1} \mathrm{H}-\mathrm{NMR},{ }^{13} \mathrm{C}-\mathrm{NMR}$, IR and single-crystal X-ray diffraction methods as well as theoretical studies have been calculated in the ground state using the HF and DFT (B3LYP) with 6-31G(d) basis set. The structural geometry and molecular electrostatic potential (MEP) properties of the title compound were studied at the HF/6-31G(d) level. The calculated geometric parameters, theoretical scaled vibrational frequencies and chemical shifts values compared with their experimental data.

\section{EXPERIMENTAL AND THEORETICAL METHODS}

\subsection{Synthesis of the Title Compound}

The title compound was synthesized as the similar manner according to the literature method [16] as depicted following Scheme 1. A solution of 0.1061 gram $(1 \mathrm{mmoL})$ of benzaldehyde and 0.9114 gram $(1 \mathrm{mmoL})$ of thiosemicarbazide in $30 \mathrm{~mL}$ of absolute ethanol and refluxed for $1 \mathrm{~h}$ (TLC) and cooled to room temperature. Subsequently, a solution of 0.2227 gram of 2-chloro-1-(3-phenyl-3methylcyclobutyl)-ethanone $(1 \mathrm{mmol})$ in absolute ethanol was added dropwise. After the addition of the $\alpha$-haloketone, the temperature was raised to 323-328 K and kept at this temperature for $2 \mathrm{~h}$ (TLC). The solution was cooled to room temperature and then made alkaline with an aqueous solution of $\mathrm{NH}_{3}$ (5\%), and black crystals separated by suction. Suitable single crystals for crystal structure determination were obtained by slow evaporation of its ethanol solution. Yield: $79 \%$. M.p.: $468 \mathrm{~K}$ $(\mathrm{EtOH})$.

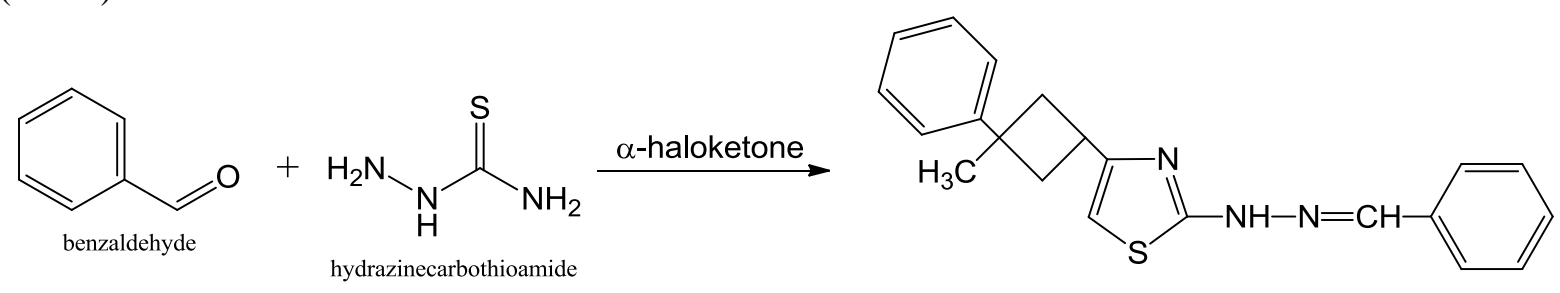

Scheme 1. Synthetic route for the synthesis of the target compound.

\subsection{General Remarks}

All chemicals were of reagent grade and used as commercially purchased without further purification. Melting point was determined by Gallenkamp melting point apparatus. The IR spectrum of the title compound was recorded in the range $4000-400 \mathrm{~cm}^{-1}$ using a Mattson 1000 FT-IR spectrometer with $\mathrm{KBr}$ pellets. The ${ }^{1} \mathrm{H}$ and ${ }^{13} \mathrm{C}$ nuclear magnetic resonance (NMR) spectra were recorded on a VarianMercury-Plus $400 \mathrm{MHz}$ spectrometer using TMS as internal standard and $\mathrm{CDCl}_{3}$ (chloroform) as solvent. 


\subsection{X-Ray Diffraction Data}

The single-crystal X-ray data was collected on a STOE diffractometer with an IPDS(II) image plate detector. All diffraction measurements were performed at room temperature (293 K) using graphite monochromated MoK $\alpha$ radiation $(\mathrm{k}=0.71073 \AA)$. Reflection data was recorded in the rotation mode using the $\omega$ scan technique by using X-AREA software [17]. Intensity parameters were collected in the $\theta$ range $2.0 \leq \theta \leq 28.1^{\circ}$. The structure was solved by direct methods using SHELXS-97 [18] implemented in the WinGX [19] program suite. The refinement was carried out by full-matrix leastsquares method on the positional and anisotropic temperature parameters of the non-hydrogen atoms, or equivalently corresponding to 226 crystallographic parameters, using SHELXL-97 [20]. All H atoms were positioned geometrically and treated using a riding model, fixing the bond lengths at 0.86 , 0.93, 0.97 and $0.96 \AA$ for $\mathrm{NH}, \mathrm{CH}, \mathrm{CH}_{2}$ and $\mathrm{CH}_{3}$ atoms, respectively. Computing data collection: $\mathrm{X}-$ AREA, cell refinement : X-AREA, computing data reduction : X-RED. The general-purpose crystallographic tool PLATON [21] was used for the structure analysis and presentation of the results. The structure was refined to $R_{\text {int }}=0.100$ with 2499 observed reflections using I $>2 \sigma$ (I) threshold. The molecular graphic were done using ORTEP-3 for Windows [22]. Details of the data collection conditions and the parameters of the refinement process are given in Table 1.

Table 1 Crystal data and structure refinement parameters for the title compound.

\begin{tabular}{ll}
\hline CCDC deposition no. & 1055300 \\
\hline Chemical formula & $\mathrm{C}_{21} \mathrm{H}_{21} \mathrm{~N}_{3} \mathrm{~S}$ \\
Formula weight & 347.47 \\
Temperature $(\mathrm{K})$ & 296 \\
Wavelength $(\AA)$ & $0.71073 \mathrm{MoK} \alpha$ \\
Crystal system & Triclinic \\
Space group & $\mathrm{P} \overline{1}$ \\
Unit cell parameters & \\
a, b, c $(\AA)$ & $5.8973(9), 10.4727(18), 15.136(2)$ \\
$\alpha, \beta, \gamma\left({ }^{\circ}\right)$ & $86.505(13), 84.242(12), 89.870(13)$ \\
Volume $\left(\AA^{3}\right)$ & $928.4(3)$ \\
$\mathrm{Z}$ & 2 \\
Calculated density $\left(\mathrm{Mg} / \mathrm{m}^{3}\right)$ & 1.243 \\
$\mu\left(\mathrm{mm}{ }^{-1}\right)$ & 0.18 \\
$\mathrm{~F}_{000}$ & 368 \\
Crystal size $(\mathrm{mm})$ & $0.70 \times 0.39 \times 0.12$ \\
$h_{\min }, h_{\max }$ & $-7,7$ \\
$k_{\min }, k_{\max }$ & $-13,13$ \\
$l_{\min }, l_{\max }$ & $-19,19$ \\
Theta range for data collection $\left(^{\circ}\right)$ & $2.0 \leq \theta \leq 28.1$ \\
Measured reflections & 11279 \\
Independent/observed reflections & $4472 / 2499$ \\
Refinement method & Full-matrix least-squares on $\mathrm{F}^{2}$ \\
$w R\left(F^{2}\right)$ & 0.147 \\
$\mathrm{R}_{\text {int }}$ & 0.100 \\
$\Delta \rho_{\max }, \Delta \rho_{\min }\left(\mathrm{e} / \AA^{3}\right)$ & $0.17,-0.27$ \\
\hline
\end{tabular}




\subsection{Quantum Chemical Calculations}

All the calculations were performed without specifying any symmetry for the title molecule by using Gauss View molecular visualization program [22] and Gaussian 03 program package [23]. For modeling, the initial guess of the compound was first obtained from the X-ray coordinates and it was optimized by Hartree-Fock (HF) and Density functional Theory (DFT)/B3LYP methods [24, 25] with the $6-31 \mathrm{G}(\mathrm{d})$ basis set. The harmonic vibrational frequencies have been calculated. The vibrational frequencies obtained for HF/6-31G(d) and DFT(B3LYP)/6-31G(d) are scaled by 0.9260 and 0.9608 $[26,27]$ respectively. We have not been found negative vibrational frequencies. ${ }^{1} \mathrm{H}-$ and ${ }^{13} \mathrm{C}-\mathrm{NMR}$ chemical shifts are calculated within GIAO approach $[28,29]$ applying HF and B3LYP method with 6-31G(d) basis set. In addition to frontier molecular orbitals and molecular electrostatic potential map were investigated by theoretical calculations.

\section{RESULTS AND DISCUSSION}

The title compound, an ORTEP view of which is shown in Fig. 1, crystallizes in the triclinic space group $\mathrm{P} \overline{1}$ with two molecules in the unit cell. The asymmetric unit in the crystal structure contains only one molecule. The title molecule is composed of a cyclobutane ring, a thiazole ring and two benzene rings.

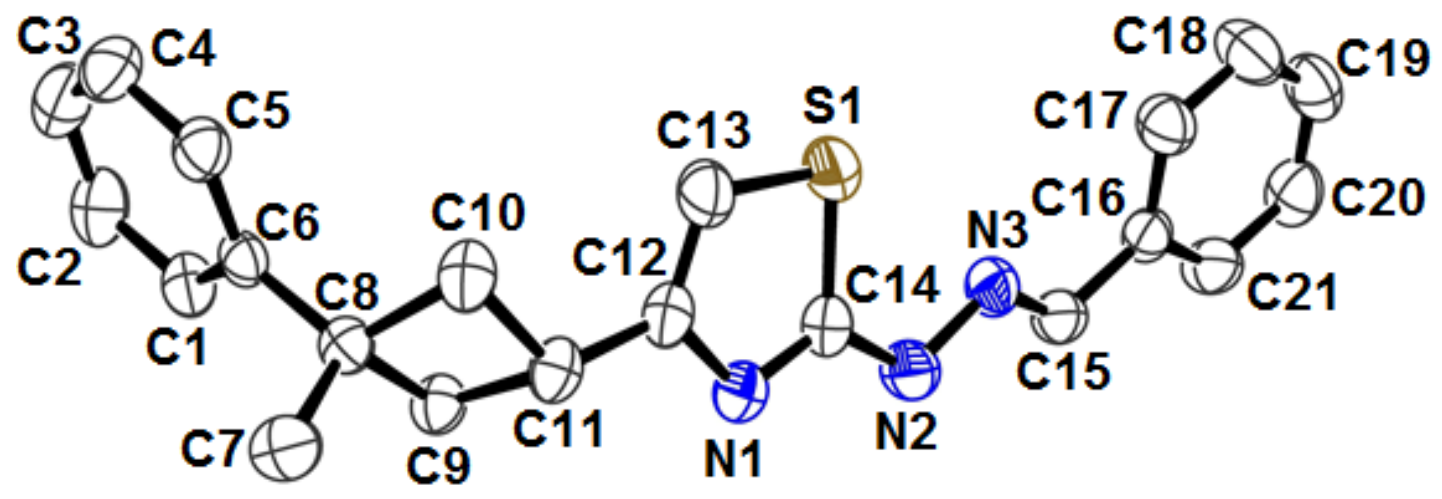

Figure 1. A view of the title compound showing the atom-numbering scheme. Displacement ellipsoids are drawn at the $30 \%$ probability level and $\mathrm{H}$ atoms have been omitted for clarity

The cyclobutane and the thiazole rings are planar with maximum deviations of $0.1121 \AA$ and 0.0044 $\AA$, respectively. The dihedral angles between the aromatic ring $\mathbf{A}(\mathrm{C} 1-\mathrm{C} 6)$, the cyclobutane plane $\mathbf{B}$ (C8-C11), and the thiazole plane $\mathbf{C}(\mathrm{S} 1 / \mathrm{N} 1 / \mathrm{C} 12-\mathrm{C} 14)$ are $41.96(10)^{\circ}(\mathbf{A} / \mathbf{B}), 50.85(11)^{\circ}(\mathbf{B} / \mathbf{C})$ and $85.19(6)^{\circ}(\mathbf{A} / \mathbf{C})$.

Cyclobutane ring is adopted puckered conformation and the value for the puckering of the cyclobutane ring found in the literature is $19.8(3)^{\circ}$ [30]. Bond length of (C7-C8) is 1.531(3) $\AA$ for mesitylene. The $\mathrm{C} 8-\mathrm{C} 9, \mathrm{C} 9-\mathrm{C} 11$ and $\mathrm{C} 8-\mathrm{C} 10$ bond lengths are 1.553(2) $\AA$, 1.556(3) $\AA$ and 1.552(3) $\AA$ respectively and the $\mathrm{C} 14-\mathrm{S} 1-\mathrm{C} 13, \mathrm{C} 8-\mathrm{C} 9-\mathrm{C} 11$ and $\mathrm{C} 11-\mathrm{C} 10-\mathrm{C} 8$ bond angles are $87.43(12)^{\circ}, 89.58(13)^{\circ}$ and $90.19(14)^{\circ}$ respectively. When the bond lengths and angles of the cyclobutane ring in the title compound are compared with the previously reported cyclobutane derivatives [31,32], it is seen that there are no significant differences.

In the thiazole ring, the S1-C13 and S1-C14 bond lengths are 1.728(3) $\AA$ and 1.722(2) $\AA$. These values are shorter than the accepted value for an S-Csp ${ }^{2}$ single bond (1.76 $\AA$ ) [33]. The C14-N1 bond length $[1.311(3) \AA]$ compares with a literature value of 1.285(7) $\AA$ [34]. The thiazole ring is planar with a r.m.s. deviation of $0.1121 \AA$. 
Perspective view of the crystal packing in the unit cell is shown in Fig. 2. The details of hydrogen bonds are given in Table 2. Atom N2 acts as donor to the symmetry-related N1 at (1-x,1-y,1-z). The imine bond length $(\mathrm{C}=\mathrm{N})$ in the literature is $1.469(4) \AA$. The $(\mathrm{N} 3=\mathrm{C} 15)$ in the crystal is $1.267(3) \AA$. It is seen that there are no significant differences, when the experimental result is compared with the literature value.

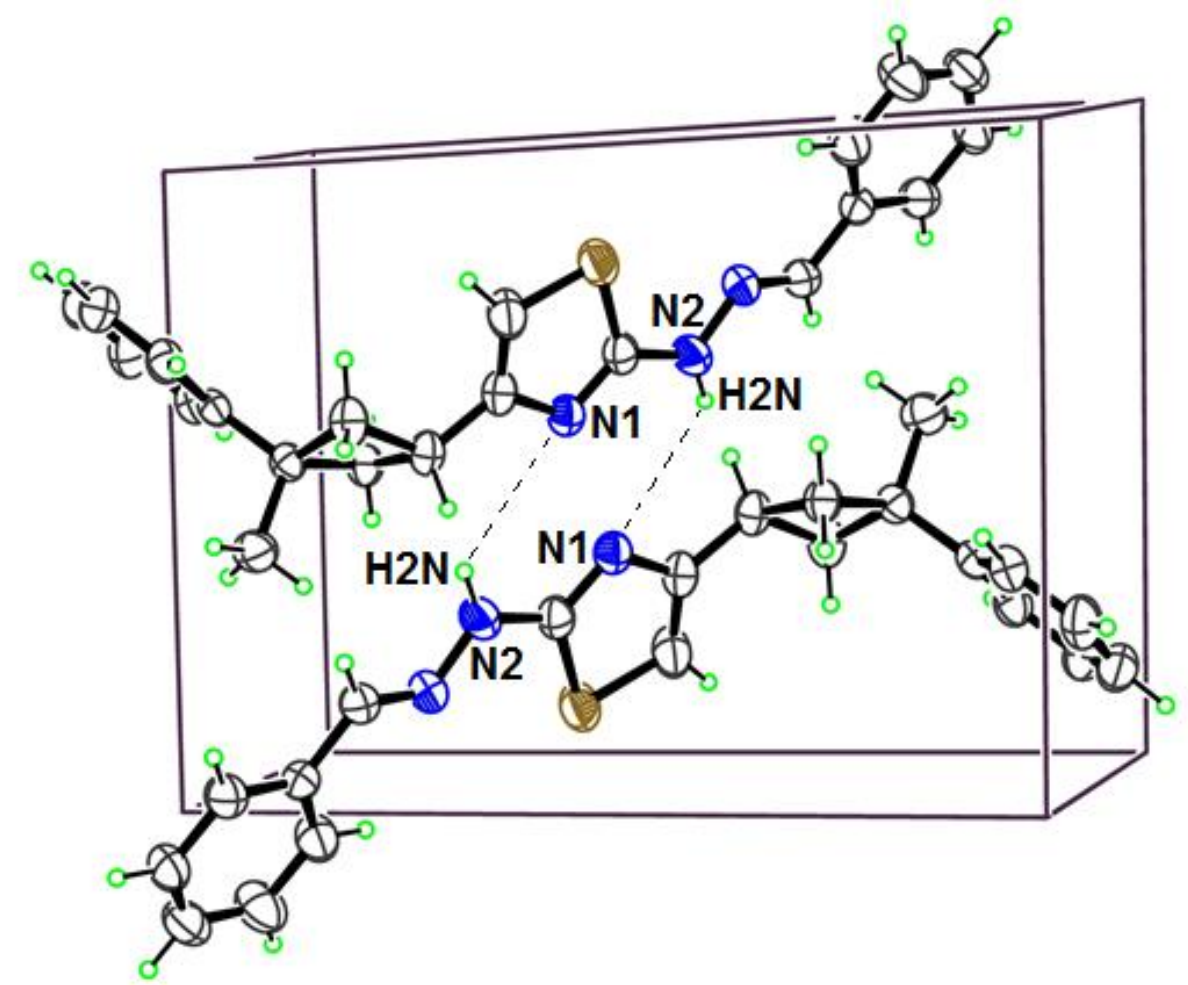

Figure 2. Part of the crystal structure of the title compound, showing the N2-H2N $\cdots \mathrm{N} 1$ interactions

Table 2. Hydrogen bond geometries in crystal structure $\left(\AA,^{\circ}\right)$

\begin{tabular}{lcccc}
\hline $\mathrm{D}-\mathrm{H} \cdots \mathrm{A}$ & $\mathrm{D}-\mathrm{H}$ & $\mathrm{H} \cdots \mathrm{A}$ & $\mathrm{D} \cdots \mathrm{A}$ & $\mathrm{D}-\mathrm{H} \cdots \mathrm{A}$ \\
\hline $\mathrm{N} 2-\mathrm{H} 2 \mathrm{~N} \cdots \mathrm{N} 1$ & 0.86 & 2.19 & $3.044(3)$ & 174 \\
\hline Symetry & & & \\
\hline
\end{tabular}

Symmetry codes : $1-\mathrm{x}, 1-\mathrm{y}, 1-\mathrm{z}$

\subsection{Optimized Structures}

The optimized parameters (bond lengths, bond angles and torsion angles) of the title compound experimentally obtained and theoretically calculated by HF and B3LYP methods with the $6-31 \mathrm{G}(\mathrm{d})$ basis set. The results listed in Table 3. Experimental data (bond lengths, bond angles and torsion angles) for the title compound compared with optimized parameters. The correlation values $\left(\mathrm{R}^{2}\right)$ have been found as $0.9890,0.9840$ for bond lengths, 0.9826, 0.9864 for bond angles, 0.9963, 0.9999 for torsion angles respectively. It is well known that DFT-optimized bond lengths are usually longer and more accurate than HF, due to the inclusion of electron correlation [35]. Thus, according to our calculations, while the HF method gave accurate results for the bond length compared with the B3LYP method, the B3LYP method gave accurate results for the bond angle compared with the HF method. In addition to the B3LYP method correlates well for the torsion angle compared with the HF method. 
Table 3 Some selected experimental and optimized geometrical parameters of the title compound

\begin{tabular}{|c|c|c|c|}
\hline \multirow{2}{*}{$\begin{array}{l}\text { Geometric } \\
\text { parameters }\end{array}$} & \multirow{2}{*}{$\begin{array}{l}\text { Experimental } \\
\text { (X-ray) }\end{array}$} & \multicolumn{2}{|c|}{ Calculated [6-31 G(d)] } \\
\hline & & $\mathbf{H F}$ & B3LYP \\
\hline \multicolumn{4}{|l|}{ Bond lengths (Å) } \\
\hline $\mathrm{C1}-\mathrm{C2}$ & $1.377(3)$ & 1.3856 & 1.3957 \\
\hline $\mathrm{C2}-\mathrm{C} 3$ & $1.361(4)$ & 1.385 & 1.3958 \\
\hline C6-C8 & $1.506(3)$ & 1.5177 & 1.5174 \\
\hline C7-C8 & $1.531(3)$ & 1.5353 & 1.5399 \\
\hline C8-C9 & $1.553(2)$ & 1.5539 & 1.5638 \\
\hline C9-C11 & $1.556(3)$ & 1.5465 & 1.5593 \\
\hline C12-C13 & $1.336(4)$ & 1.3386 & 1.3635 \\
\hline C12-N1 & $1.394(2)$ & 1.3865 & 1.3891 \\
\hline C14-N1 & $1.311(3)$ & 1.277 & 1.3015 \\
\hline C13-S1 & $1.728(3)$ & 1.746 & 1.7525 \\
\hline C14-S1 & $1.722(2)$ & 1.7385 & 1.7583 \\
\hline $\mathrm{C} 14-\mathrm{N} 2$ & $1.360(3)$ & 1.364 & 1.3731 \\
\hline $\mathbf{N} 2-\mathbf{N 3}$ & $1.372(3)$ & 1.3505 & 1.3461 \\
\hline C15-N3 & $1.267(3)$ & 1.2555 & 1.2879 \\
\hline C15-C16 & $1.465(3)$ & 1.4743 & 1.4614 \\
\hline C16-C17 & $1.368(3)$ & 1.3946 & 1.4076 \\
\hline C16-C21 & $1.378(3)$ & 1.3887 & 1.4047 \\
\hline $\mathbf{R}^{2}$ & & 0.9890 & 0.9840 \\
\hline \multicolumn{4}{|l|}{ Bond angles $\left({ }^{\circ}\right)$} \\
\hline C9-C8-C7 & $113.12(17)$ & 111.6951 & 111.6873 \\
\hline C7-C8-C10 & $112.02(17)$ & 111.7366 & 111.685 \\
\hline C13-S1-C14 & $87.43(12)$ & 87.5904 & 87.3223 \\
\hline N1-C14-N2 & $125.0(2)$ & 122.0153 & 122.3507 \\
\hline N3-C15-C16 & $120.8(2)$ & 122.3866 & 122.2739 \\
\hline C17-C16-C21 & $117.7(2)$ & 119.1734 & 118.8291 \\
\hline $\mathbf{R}^{2}$ & & 0.9826 & 0.9864 \\
\hline \multicolumn{4}{|l|}{ Torsion angles $\left({ }^{\circ}\right)$} \\
\hline C1-C6-C8-C10 & $136.73(18)$ & 141.7235 & 141.5944 \\
\hline C5-C6-C8-C9 & $-144.34(18)$ & -143.1577 & -143.1639 \\
\hline N3-N2-C14-S1 & $2.9(2)$ & -12.4184 & 2.8767 \\
\hline N2-N3-C15-C16 & $-178.55(19)$ & -178.9846 & -179.9624 \\
\hline C16-C17-C18-C19 & $-0.1(4)$ & 0.0102 & 0.0035 \\
\hline $\mathbf{R}^{2}$ & & 0.9963 & 0.9999 \\
\hline
\end{tabular}

We note that the experimental results belongs to solid phase and the theoretical calculations belongs to gas phase. In the solid state, the existence of a crystal field along with the intermolecular interactions connect the molecules together, which results in the differences in bond parameters between the calculated and experimental values [36].

A global comparison was performed by superimposing the molecular skeletons obtained from X-ray diffraction and the theoretical calculations atom by atom (Fig. 3), obtaining RMSE values of 0.345 and $0.369 \AA$ for HF/6-31G(d) and B3LYP/6-31G(d), respectively. According to this results, the smallest RMSE value is obtained for $\mathrm{HF} / 6-31 \mathrm{G}(\mathrm{d})$ and the geometry obtained from this method coincides better with the crystalline structure than B3LYP/6-31G(d) method. For that reason, we used the geometry from $\mathrm{HF} / 6-31 \mathrm{G}(\mathrm{d})$ method, to calculate molecular electrostatic potential (MEP) and frontier molecular orbitals (FMOs). 

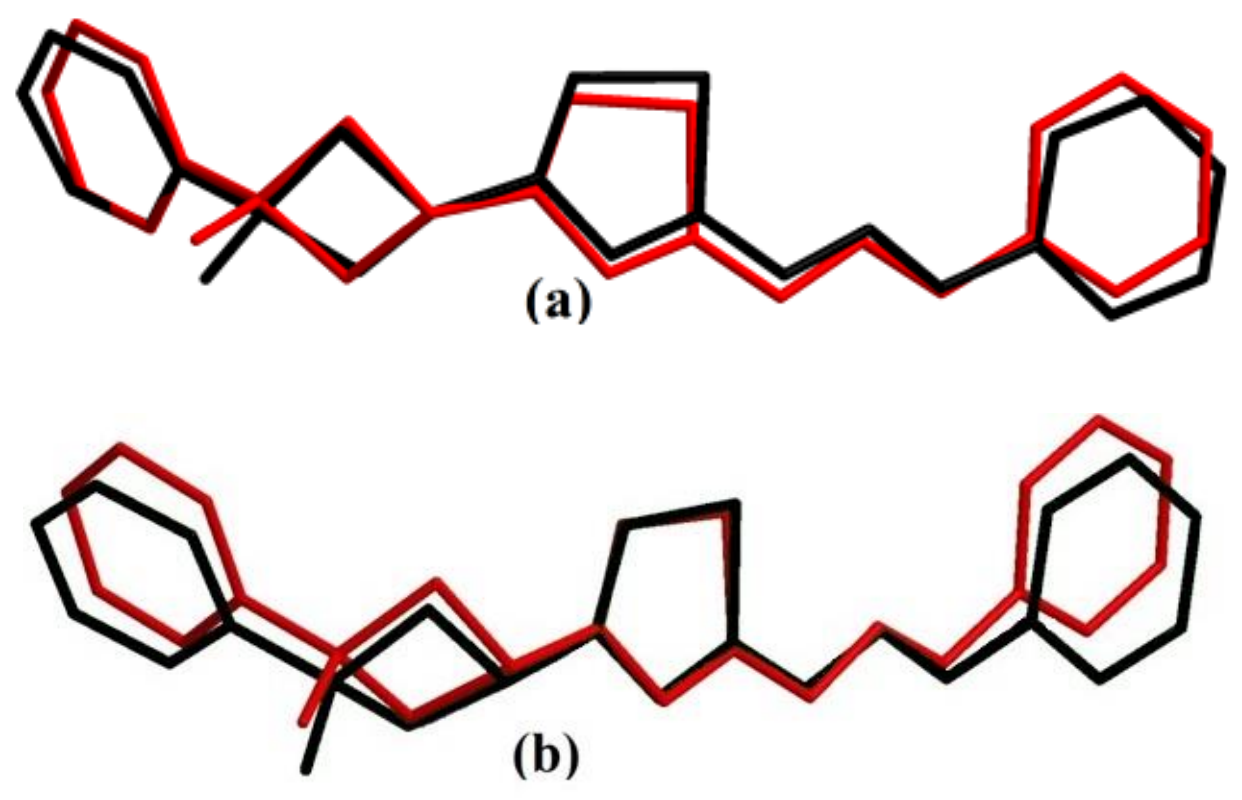

Figure 3. Atom-by atom superimposition of the calculated structures calculated (black) $(\mathrm{a}=\mathrm{HF} / 6$ $31 \mathrm{G}(\mathrm{d}), \mathrm{b}=\mathrm{B} 3 \mathrm{LYP} / 6-31 \mathrm{G}(\mathrm{d}))$ on the X-ray structure (red) of the title compound

\subsection{IR Spectroscopy}

The experimental IR spectra of the title compound are shown in Fig 4. It is compared the calculated vibrational frequencies with their experimental data. The correlation values $\left(\mathrm{R}^{2}\right)$ have been found as 0.9951, 0.9967 for HF and B3LYP methods respectively. Experimental and theoretical vibrational frequencies of the title molecule are shown in Table 4.

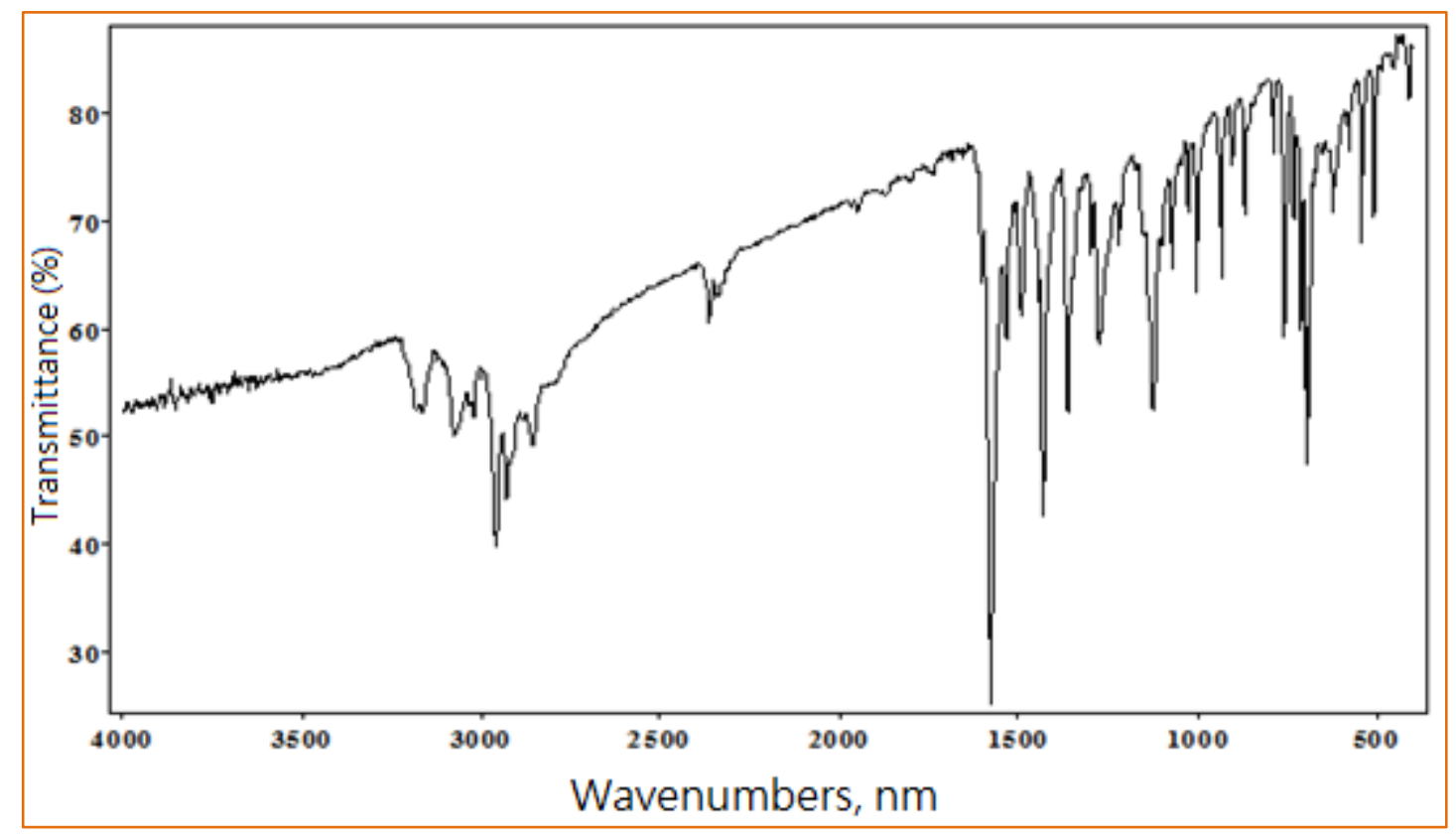

Figure 4. Experimental IR spectra of the title compound 
Ferah et al. / Anadolu Univ. J. of Sci. and Tech. B - Theoretical Sci. 4 (2) - 2016

Table 4. Comparision of the observed and calculated vibrational spectra of the title compound

\begin{tabular}{lccc}
\hline Assignment & Experimental FT-IR $\left(\mathrm{cm}^{-1}\right)$ & Calculated [6-31 G(d)] \\
\hline$v \mathrm{~N}-\mathrm{H}$ & 3259 & 3397 & 3356 \\
$v_{\text {as }} \mathrm{C}-\mathrm{H}_{\text {aromatic }}$ & 3105 & 3013 & 3126 \\
$v_{\text {as }} \mathrm{C}-\mathrm{H}_{\text {2cyclobutane }}$ & 2957 & 2934 & 2978 \\
$v \mathrm{C}-\mathrm{H}_{\text {cyclobutane }}$ & 2864 & 2890 & 2854 \\
$v \mathrm{C}=\mathrm{C}_{\text {aromatic }}$ & 1680 & 1680 & 1675 \\
$v \mathrm{C}=\mathrm{C}_{\text {thiazole }}+v \mathrm{C}=\mathrm{N}_{\text {thiazole }}$ & 1630 & 1572 & 1502 \\
$\beta \mathrm{C}-\mathrm{H}_{\text {aromatic }}$ & 1282 & 1258 & 1299 \\
$v \mathrm{~S}-\mathrm{C}-\mathrm{N}_{\text {thiazole }}$ & 737 & 767 & 750 \\
$\mathrm{R}^{2}$ & & 0.9951 & 0.9967 \\
\hline
\end{tabular}

Vibrational modes: $v$, stretching; $\beta$, bending; s, symmetric; as, asymmetric

The N-H stretching vibrations occur in the region $3300-3500 \mathrm{~cm}^{-1}$ [37]. The hetero aromatic molecule containing $\mathrm{N}-\mathrm{H}$ group shows its stretching absorption in the region $3500-3220 \mathrm{~cm}^{-1}[38,39]$. In this study, the $\mathrm{N}-\mathrm{H}$ stretching vibration is recorded at $3259 \mathrm{~cm}^{-1}$ as a very strong band in FT-IR spectrum and its corresponding calculated frequency is $3397,3356 \mathrm{~cm}^{-1}$ using $\mathrm{HF} / 6-31 \mathrm{G}(\mathrm{d})$ and B3LYP/6$31 \mathrm{G}(\mathrm{d})$ respectively.

The hetero aromatic structure shows the presence of $\mathrm{C}-\mathrm{H}$ stretching vibrations in the range 3000-3100 $\mathrm{cm}^{-1}$, which is the characteristic region for $\mathrm{vC}-\mathrm{H}$ stretching [40]. The experimental $\mathrm{C}-\mathrm{H}$ asymmetric stretching vibrations was observed at $3105 \mathrm{~cm}^{-1}$, which has been calculated at $3013 \mathrm{~cm}^{-1}$ and $3126 \mathrm{~cm}^{-}$ ${ }^{1}$ for HF and B3LYP methods.

\section{4. ${ }^{1} \mathrm{H}$ and ${ }^{13} \mathrm{C}$ NMR Spectra}

The characterization of the compound was further enhanced by the use of ${ }^{1} \mathrm{H}$ and ${ }^{13} \mathrm{C}$ NMR spectroscopy. The ${ }^{1} \mathrm{H}$ and ${ }^{13} \mathrm{C}$ NMR spectra of the title compound recorded using TMS as an internal standart and chloroform $\left(\mathrm{CDCL}_{3}\right)$ as solvent. GIAO ${ }^{1} \mathrm{H}$ and ${ }^{13} \mathrm{C}$ chemical shift values (with respect to TMS) were calculated using the HF and B3LYP methods with the 6-31 G(d) basis set were compared to the experimental ${ }^{1} \mathrm{H}$ and ${ }^{13} \mathrm{C}$ chemical shift values. Experimental NMR spectrum (experimental results belongs to solid phase) and the calculated results (theoretical calculations belongs to gas phase) are given in Fig.5 and Table 5, respectively. 


\section{(a) ${ }^{1} \mathrm{H}$ NMR}

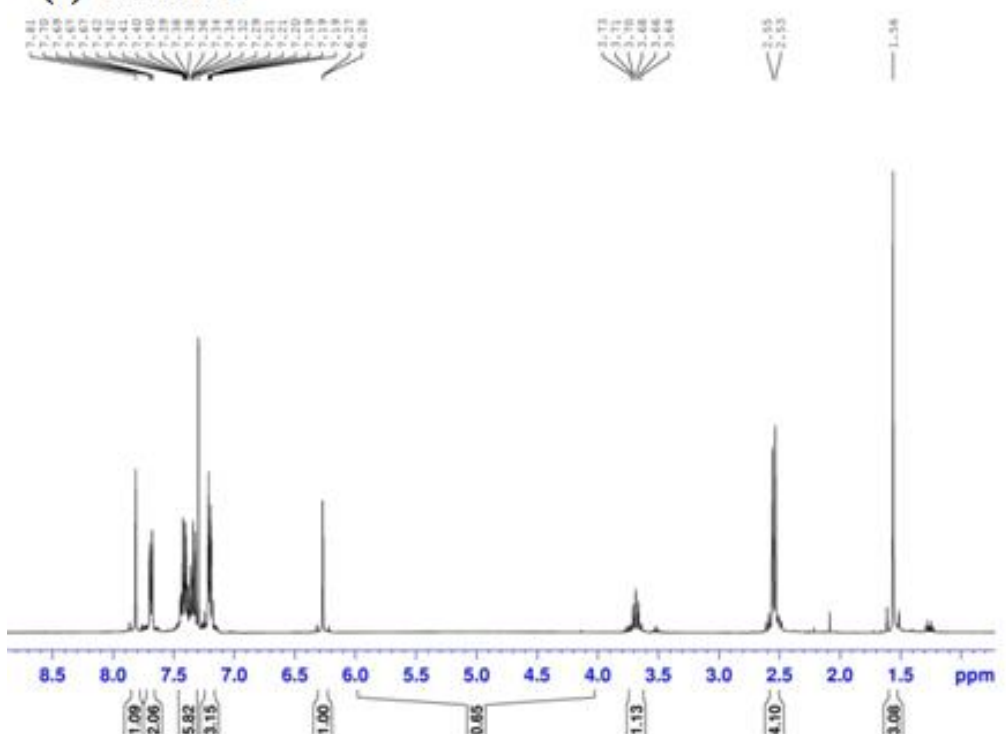

(b) ${ }^{13}$ C NMR

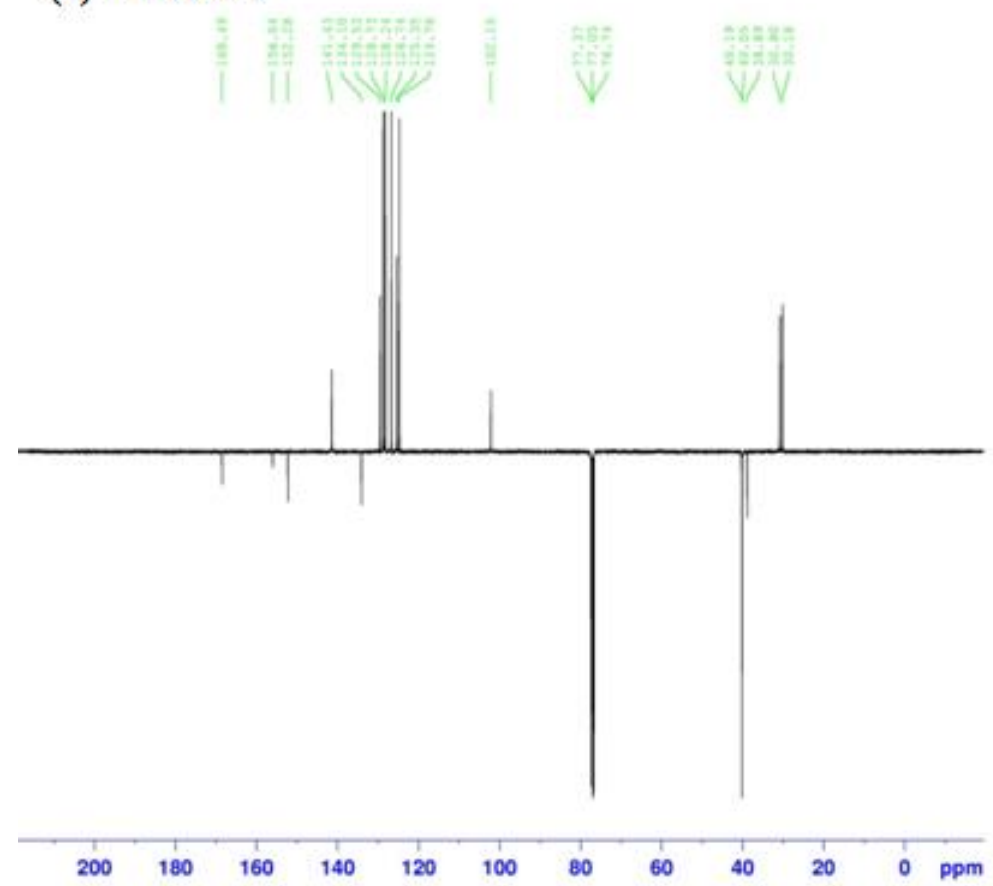

Figure 5. Experimental (a) ${ }^{1} \mathrm{H}$ and (b) ${ }^{13} \mathrm{C}$ chemical shift spectra of the title compound 
Table 5. The experimental and calculated ${ }^{1} \mathrm{H}$ and ${ }^{13} \mathrm{C}$ isotropic chemical shifts (with respect to TMS, all values in $\mathrm{ppm}$ ) for title compound

\begin{tabular}{|c|c|c|c|}
\hline \multirow{2}{*}{ Atom } & \multirow[t]{2}{*}{ Experimental (ppm) $\mathrm{CDCl}_{3}$} & \multicolumn{2}{|c|}{ Calculated (ppm) [6-31 G(d)] } \\
\hline & & $\mathrm{HF}$ & B3LYP \\
\hline $\mathrm{C} 1$ & 124.76 & 117.64 & 121.05 \\
\hline $\mathrm{C} 2$ & 126.74 & 119.47 & 122.62 \\
\hline $\mathrm{C} 3$ & 125.36 & 113.48 & 117.89 \\
\hline $\mathrm{C} 4$ & 126.74 & 119.41 & 122.57 \\
\hline $\mathrm{C} 5$ & 124.76 & 117.60 & 121.14 \\
\hline C6 & 152.28 & 149.22 & 155.02 \\
\hline $\mathrm{C} 7$ & 30.18 & 8.85 & 18.53 \\
\hline $\mathrm{C} 8$ & 38.89 & 25.05 & 42.88 \\
\hline C9 & 40.05 & 23.91 & 37.52 \\
\hline $\mathrm{C} 10$ & 40.19 & 20.39 & 33.39 \\
\hline $\mathrm{C} 11$ & 30.80 & 15.46 & 29.32 \\
\hline $\mathrm{C} 12$ & 156.04 & 152.43 & 157.58 \\
\hline $\mathrm{C} 13$ & 102.15 & 95.74 & 108.29 \\
\hline $\mathrm{C} 14$ & 168.49 & 179.82 & 173.15 \\
\hline $\mathrm{C} 15$ & 141.43 & 139.64 & 138.69 \\
\hline $\mathrm{C} 16$ & 134.10 & 128.10 & 135.61 \\
\hline $\mathrm{C} 17$ & 128.73 & 117.04 & 119.01 \\
\hline $\mathrm{C} 18$ & 128.24 & 118.17 & 122.68 \\
\hline C19 & 129.53 & 118.33 & 120.89 \\
\hline $\mathrm{C} 20$ & 128.24 & 117.96 & 122.74 \\
\hline $\mathrm{C} 21$ & 128.73 & 120.58 & 123.47 \\
\hline $\mathrm{H} 1^{\mathrm{a}}$ & $7.32-7.36$ & 4.80 & 5.08 \\
\hline $\mathrm{H} 2$ & 7.21 & 5.07 & 5.33 \\
\hline $\mathrm{H} 3$ & 7.19 & 4.72 & 5.07 \\
\hline $\mathrm{H} 4$ & 7.21 & 5.12 & 5.37 \\
\hline $\mathrm{H} 5^{\mathrm{a}}$ & $7.32-7.36$ & 4.90 & 5.20 \\
\hline H6 & 1.56 & 2.98 & 2.54 \\
\hline $\mathrm{H} 7$ & 1.56 & 3.02 & 2.59 \\
\hline $\mathrm{H} 8$ & 1.56 & 2.66 & 2.11 \\
\hline $\mathrm{H}^{\mathrm{a}}$ & $2.53-2.55$ & 0.76 & 0.11 \\
\hline $\mathrm{H} 10^{\mathrm{a}}$ & $2.53-2.55$ & 1.07 & 0.47 \\
\hline $\mathrm{H} 11^{\mathrm{a}}$ & $2.53-2.55$ & 0.97 & 0.32 \\
\hline $\mathrm{H} 12^{\mathrm{a}}$ & $2.53-2.55$ & 0.82 & 0.23 \\
\hline H13 & 3.68 & 0.10 & 0.94 \\
\hline H14 & 6.26 & 3.78 & 4.42 \\
\hline H15 & 7.39 & 3.72 & 6.18 \\
\hline H16 & 7.81 & 5.09 & 5.07 \\
\hline H18 & 7.40 & 5.04 & 5.30 \\
\hline H19 & 7.38 & 5.12 & 5.24 \\
\hline $\mathrm{H} 20$ & 7.38 & 5.07 & 5.31 \\
\hline $\mathrm{H} 21^{\mathrm{a}}$ & $7.67-7.70$ & 4.90 & 5.05 \\
\hline
\end{tabular}

${ }^{a}$ Average

We have calculated ${ }^{1} \mathrm{H}$ chemical shift values (with respect to TMS) of 5.12-0.10 and $\quad 6.18-0.11$ ppm at the HF/6-31G(d) and B3LYP/6-31G(d) level, respectively, however the experimental results were observed to be 7.81-1.56 ppm. In the ${ }^{1} \mathrm{H}$ NMR spectra of the compound, the chemical shift values of $\mathrm{C}-\mathrm{H}_{3}$ protons were observed to be $1.56 \mathrm{ppm}$. These signals have been calculated as $2.89^{\mathrm{a}}$ and $2.41^{\mathrm{a}} \mathrm{ppm}$ for HF and B3LYP methods with the 6-31G(d) level, respectively. The $-\mathrm{CH}_{2}-$ signals of the cyclobutane are observed at $2.53-2.55 \mathrm{ppm}$. The aromatic $\mathrm{H}$ atoms were observed to be 5.07-5.37 $(\mathrm{H} 1, \mathrm{H} 2, \mathrm{H} 3, \mathrm{H} 4, \mathrm{H} 5) \mathrm{ppm}$. 
We have calculated ${ }^{13} \mathrm{C}$ chemical shift values (with respect to TMS) of 179.82-8.85 and 173.15-18.53 ppm at the HF/6-31G(d) and B3LYP/6-31G(d) level, respectively, however the experimental results were observed to be 168.49-30.18 ppm. ${ }^{13} \mathrm{C}$ NMR spectra of the thiazole compound show the signals at 102.15-168.49 ppm due to $\mathrm{C}$ atoms. These signals have been founded are 111.969-165.219 ppm in the literature [41]. These signals have been calculated as 95.74-179.82 ppm for the HF level, 108.29$173.15 \mathrm{ppm}$ for B3LYP level. To make comparision with experimental observations, we present correlation graphs in Fig. 6 based on the calculations. This correlation values $\left(\mathrm{R}^{2}\right)$ have been found as 0.9901 and 0.9966 for HF and B3LYP methods with the 6-31G(d) level, respectively. As can be seen from Table 5, the theoretical ${ }^{1} \mathrm{H}$ and ${ }^{13} \mathrm{C}$ chemical shift results for the title compound are close to the experimental ${ }^{1} \mathrm{H}$ and ${ }^{13} \mathrm{C}$ shift data.

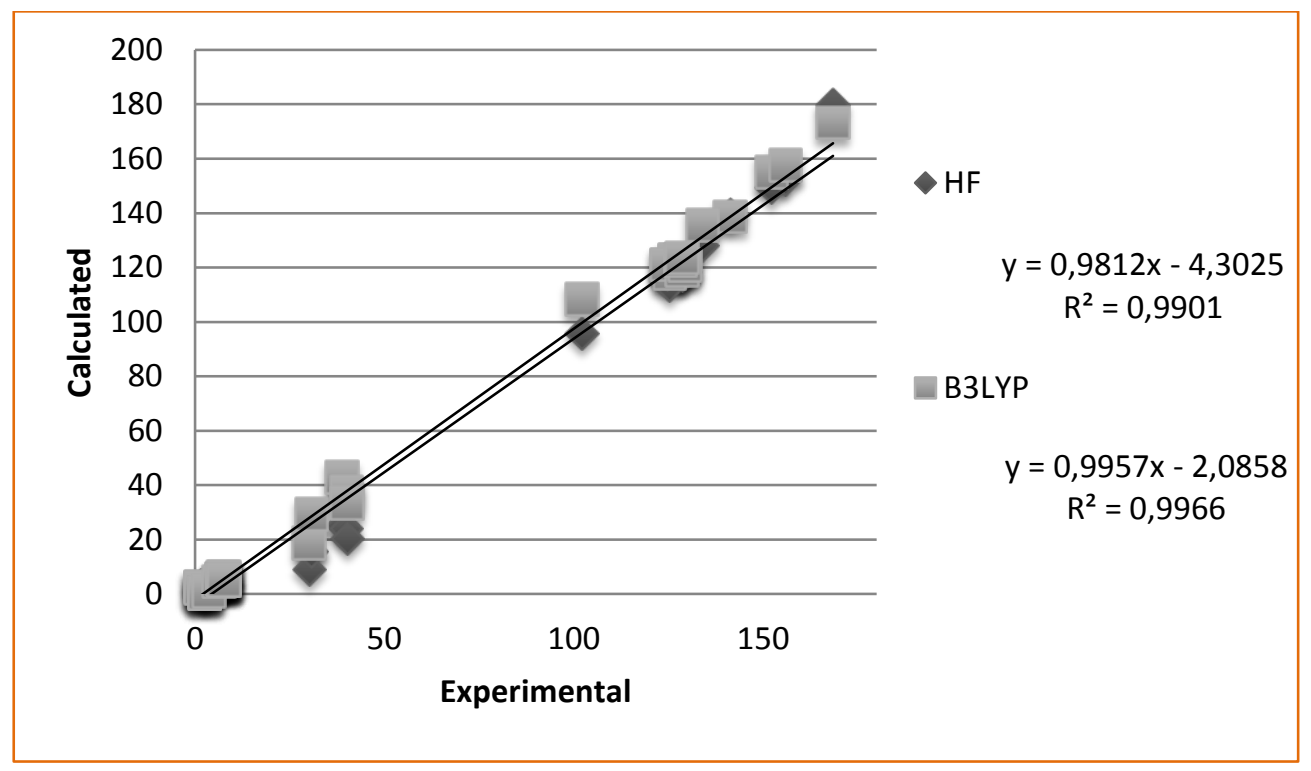

Figure 6. Correlation graphics between the experimental and theoretical NMR chemical shift values of the title compound

\subsection{Molecular Electrostatic Potential (MEP)}

The molecular electrostatic potential, $V(r)$, at a given point $r(x, y, z)$ in the vicinity of a molecule, is defined in terms of the interaction energy between the electrical charge generated from the molecule electrons and nuclei and a positive test charge (a proton) located at $r$. For the system studied, the $V(r)$ values were calculated as described previously using the equation [42].

$$
V(r)=\sum \frac{Z_{A}}{\left|R_{A}-r\right|}-\int \frac{\rho\left(r^{\prime}\right)}{\left|r^{\prime}-r\right|} d^{3} r^{\prime}
$$

where $Z_{A}$ is the charge of nucleus A located at $R_{A}, \rho\left(r^{\prime}\right)$ is the electronic density function of the molecule, and $r^{\prime}$ is the dummy integration variable.

The molecular electrostatic potential (MEP) is related to the electronic density and is a very useful descriptor in understanding sites of electrophilic attack and nucleophilic reactions as well as hydrogen bonding interactions [43-45]. The electrostatic potential $V(r)$ is also well suited for analyzing processes based on the 'recognition' of one molecule by another, such as in drug-receptor, and enzyme-substrate interactions, because it is through their potentials that the two species first 'see' each other [46-48]. Being a real physical property, $V(r)$ can be determined experimentally by diffraction or by computational methods [49]. 
To visiually consider the most probable sites of the title molecule for an interaction with electrophilic and nucleophilic species, MEP was calculated at the HF/6-31G(d) optimized geometry. According to our calculations, $\mathrm{HF} / 6-31 \mathrm{G}(\mathrm{d})$ method gave accurate results for the molecular electrostatic potential compared with the B3LYP/6-31G(d) method. Therefore we have choosen HF/6-31G(d) method for the Mep. While electrophilic reactivities visualized by red color which indicate the negative regions of the molecule, the nucleophilic reactivities colored by blue, indicating the positive regions of the molecule as shown Fig. 7.
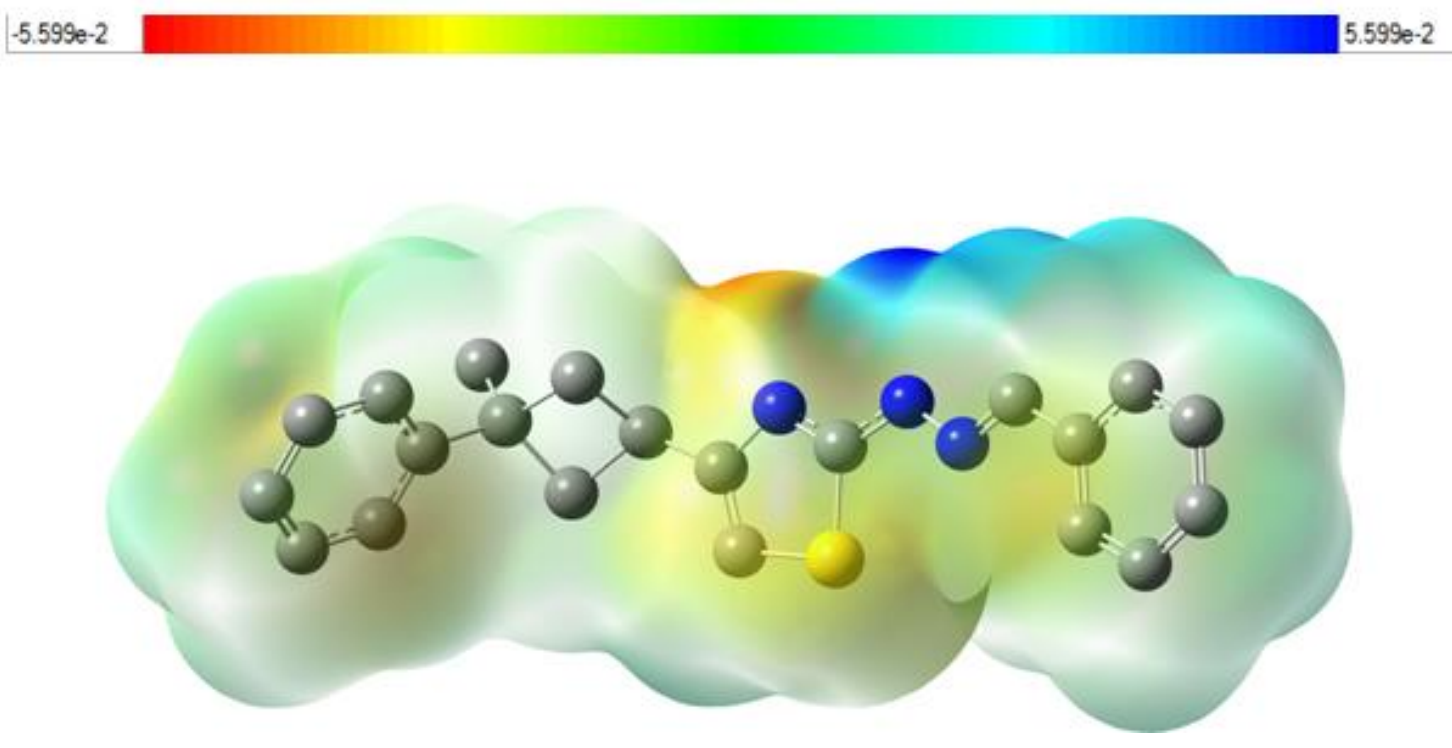

Figure 7. Molecular electrostatic potential map (MEP) (in a.u.) calculated at HF/6-31G(d) level

\subsection{HOMO and LUMO Analysis}

The frontier molecular orbitals play an important role in the electric and optical properties, as well as in UV-Vis spectra and chemical reactions [50]. By examining the frontier orbitals of a molecule the optical properties and the steps to react with other molecules can be determined. The calculations indicate that the title compound has 92 occupied molecular orbitals. Fig. 8 shows the distributions and energy levels of the HOMO and LUMO orbitals computed at the HF/6-31G(d) level for the title compound. Both the highest occupied molecular orbitals (HOMOs) and the lowest-lying unoccupied molecular orbitals (LUMOs) are mainly localized on the rings. Besides, Gauss-Sum 2.2 Program [51] was used to calculate group contributions to the molecular orbitals.

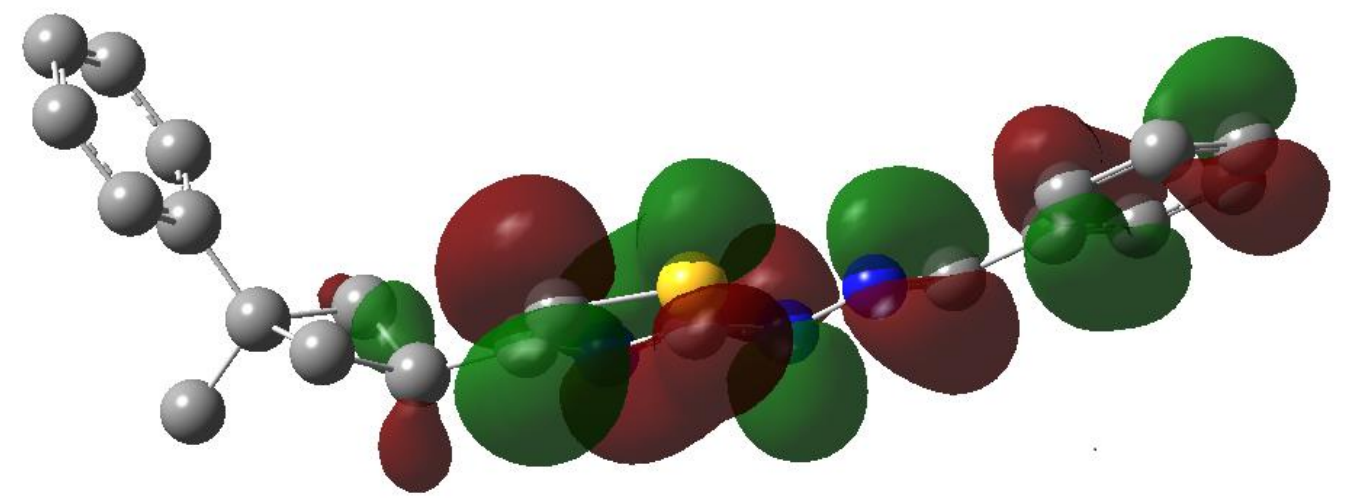

HOMO (-7.74 eV) 


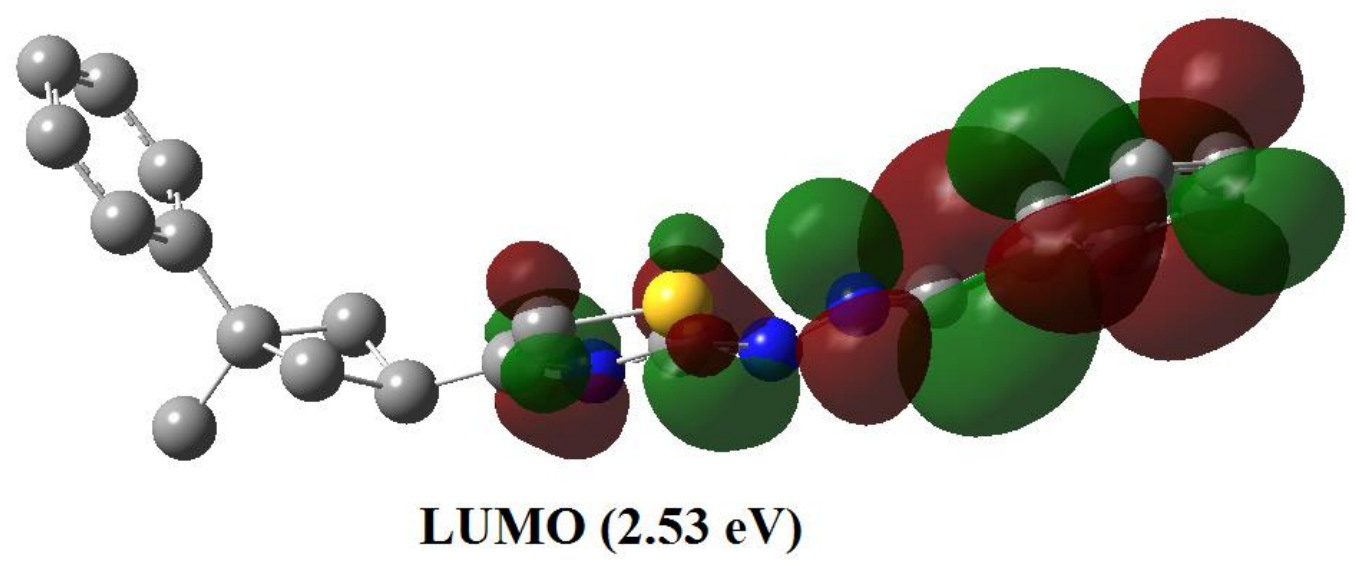

Figure 8. Molecular orbital surfaces and energy levels given in parentheses for the HOMO and LUMO of the title compound computed at HF/6-31G(d) level.

\subsection{Mulliken Atomic Charges}

The charge distributions calculated by the Mulliken method [52] for the equilibrium geometry of the title compound. The corresponding Mulliken's plot is shown in Fig. 9. As can be seen from the Fig. 9, charge of the $\mathrm{N} 2, \mathrm{H} 2 \mathrm{~N}$ and $\mathrm{N} 1$ atom of $-0.602,+0.392$ and -0.605 for the HF/6-31G(d) methods respectively. From the results it is clear that the Mulliken's charges are confirmed to the intermolecular bond $\mathrm{N} 2-\mathrm{H} 2 \mathrm{~N} \cdots \mathrm{N} 1$ in the crystal.

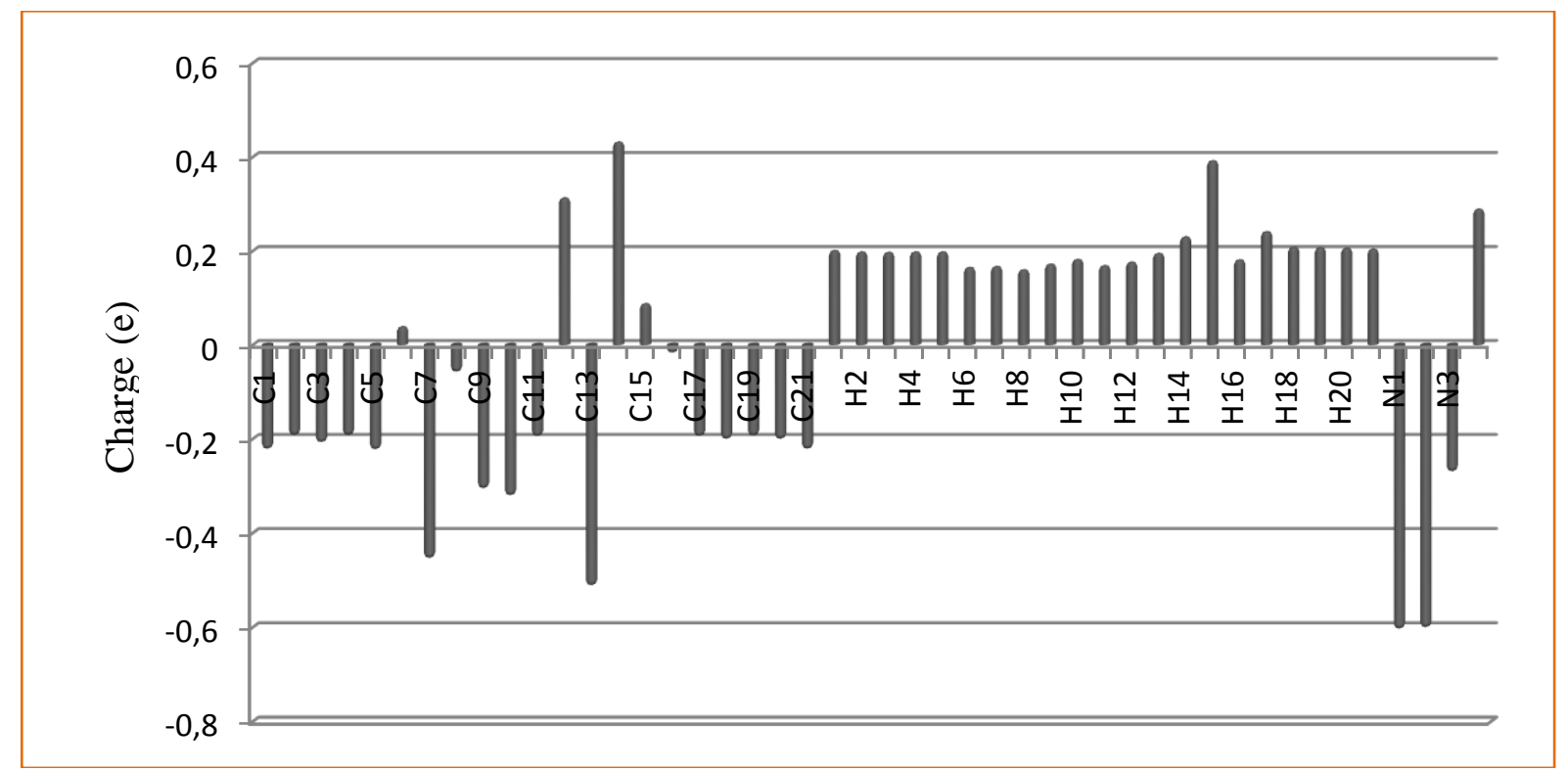

Figure 9. The charge distribution calculated by the Mulliken method for the title molecule

\section{CONCLUSIONS}

In this work, 2-(2-benzylidenehydrazinyl)-4-(3-methyl-3-phenylcyclobutyl)thiazole, was prepared and characterized by spectroscopic (FT-IR and NMR) and structural (single-crystal X-ray diffraction) techniques. Calculation based on Hartree-Fock (HF)/6-31G(d) and DFT B3LYP/6-31G(d) methods were performed to further study on the molecular structure and vibrational spectra for the title 
compound. The comparisons between the calculated results and the X-ray experimental data indicate that B3LYP method is better than HF method in evaluating torsion and bond angles. The calculated results show that the optimized geometries can well reproduce the crystal structure, and the theoretical vibrational frequencies and chemical shift values. The MEP map shows that the negative potential sites are on electronegative atoms and the positive potential sites are around the hydrogen atoms. These sites provide information concerning the region fromwhere the compound can undergo intraand intermolecular interactions. The value of the energy separation between the HOMO and LUMO is very large and this energy gap gives significant information about the title compound. Mulliken charges confirm the intermolecular hydrogen bonds in the crystal structure.

\section{ACKNOWLEDGMENTS}

I wish to thank Prof. Dr. Orhan Büyükgüngör for his help with the data collection and acknowledge the Faculty of Arts and Sciences, Ondokuz Mayis University, Turkey, for the use of the STOE IPDS II diffractometer.

\section{SUPPLEMENTARY DATA}

CCDC-1055300 contains the supplementary crystallographic data for the compound reported in this article. These data can be obtained free of charge at www.ccdc.cam.ac.uk/conts/retrieving.html [or from the Cambridge Crystallographic Data Centre (CCDC), 12 Union Road, Cambridge CB2 1EZ, UK; fax:+44(0)1223-336033; e-mail: deposit@ccdc.cam.ac.uk].

\section{REFERENCES}

[1] Dehmlow EV, Schmidt S. Synthesis of Stereoisomeric 3-Substituted cyclobutanecarboxylic acidderivatives. Liebigs Ann Chem 1990; 5: 411-414.

[2] Coghi L, Lanfredi AMM, Tiripicchio A. Crystal and molecular structure of thiosemicarbazide hydrochloride. J Chem Soc Perkin Trans 1976; 2: 1808-1810.

[3] Edward LR, Mladenova G. Enantiomerically Pure Cyclobutane Derivatives and Their Use in Organic Synthesis. Chem Rev 2003; 103: 1449-1484.

[4] Namyslo JC, Kaufmann DE. The application of cyclobutane derivatives in organic synthesis. Chem Rev 2003; 103: 1485-1537.

[5] Barone R, Chanon M, Gallo R. Aminothiazoles and Their Derivatives: The Chemistry of Heterocyclic Compounds. Interscience Publishers, Wiley, New York, 1979; 34: 9-366.

[6] Lesyk R, Vladzimirska O, Holota S, Zaprutko L, Gzella A. New 5-substituted thiazolo[3,2b][1,2,4]triazol-6-ones: Synthesis and anticancer evaluation. Eur J Med Chem 2007; 42: 641-648.

[7] Lesyk R, Zimenkovsky B, Atamanyuk D, Jensen F, Kiec-Kononowicz K, Gzella A. Anticancer thiopyrano[2,3-d][1,3]thiazol-2-ones with norbornane moiety. Synthesis, cytotoxicity, physicochemical properties, and computational studies. Bioorg Med Chem 2006; 14: 5230-5240.

[8] Siddiqui N, Ahsan W. Triazole incorporated thiazoles as a new class of anticonvulsants: design, synthesis and in vivo screening. Eur J Med Chem 2010; 45: 1536-1543.

[9] Satoh A, Nagatomi Y, Hirata Y, Ito S, Suzuki G, Kimura T, Maehara S, Hikichi H, Satow A, Hata M, Ohta H, Kawamoto H. Discovery and in vitro and in vivo profiles of 4-fluoro-N-[4-[6- 
(isopropylamino) pyrimidin-4-yl]-1,3-thiazol-2-yl]-N-methylbenzamide as novel class of an orally active metabotropic glutamate receptor 1 (mGluR1) antagonist. Bioorg Med Chem Lett 2009; 19: $5464-5468$.

[10] Abdel-Wahab BF, Abdel-Aziz HA, Ahmad EM. Synthesis and antimicrobial evaluation of 1(benzofuran-2-yl)-4-nitro-3-arylbutan-1-ones and 3-(benzofuran-2-yl)-4,5-dihydro-5-aryl-1-[4-(aryl)1,3-thiazol-2-yl]-1H-pyrazoles. Eur J Med Chem 2009; 44: 2632-2635.

[11] Vijaya Raj KK, Narayana B, Ashalatha BV, Suchetha Kumari N, Sarojini BK. Synthesis of some bioactive 2-bromo-5-methoxy- $N$ '-[4-(aryl)-1,3-thiazol-2-yl]benzohydrazide derivatives. Eur $\mathrm{J}$ Med Chem 2007; 42: 425-429.

[12] Shiradkar MR, Murahari KK, Gangadasu HR, Suresh T, Kalyan CA, Kaur DPR, Burange P, Ghogare J, Mokale V, Raut M. Synthesis of new Sderivatives of clubbed triazolyl thiazole as antiMycobacterium tuberculosis agents. Bioorg Med Chem 2007; 15: 3997-4008.

[13] Shiradkar M, Kumar GVS, Dasari V, Tatikonda S, Akula KC, Shah R. Clubbed triazoles: a novel approach to antitubercular drugs. Eur J Med Chem 2007; 42: 807-816.

[14] Koz'minykh VO, Milyutin AV, Makhmudov RR, Belyaev AO, Koz'minykh EN. Substituted amides and hydrazides of acylpyruvic acids. Part 11. Synthesis and biological activity of 4-aryl-2hydroxy-4-oxo-2-butenoic acid n-(1,3-thiazol-2-yl)amides. Pharm Chem J 2004; 38: 665-669.

[15] Sen F, Dincer M, Cukurovali A, Yilmaz I. N-[4-(3-methyl-3-mesityl-cyclobutyl)-thiazol-2-yl]succinamic acid: X-ray structure, spectroscopic characterization and quantum chemical computational studies. J Mol Struc 2013; 1046: 1-8.

[16] Genc S, Dege N, Yilmaz I, Cukurovali A, Dincer M. 5-Bromo-2-hydroxybenzaldehyde (4phenyl-1,3-thiazol-2-yl)hydrazone. Erratum. Acta Cryst 2004; E60: o889-o891.

[17] Stoe \& Cie, X-AREA Version 1.18; Stoe \& Cie, Darmstadt, 2002.

[18] Sheldrick GM, SHELXS-97; Program for the Solution of Crystal Structures, University of Gottingen, 1997.

[19] Farrugia LJ. WinGX suite for smallmolecule single-crystal crystallography. J Appl Crystallogr. 1999; 32: 837-838.

[20] Sheldrick GM. SHELXL-97; Program for Crystal Structures Refinement, University of Gottingen, 1997.

[21] Spek AL. Structure validation in chemical crystallography. Acta Crystallogr 2009; D65: 148-155.

[22] Dennington II R, Keith T, Millam J, Gauss View, Version 4.1.2, Semichem Inc, Shawnee Mission, KS, 2007.

[23] Frisch MJ, Trucks GW, Schlegel HB, Scuseria GE, Robb MA, Cheeseman JR, Montgomery Jr JA, Vreven T, Kudin K.N, Burant J.C, Millam J.M, Iyengar SS, Tomasi J, Barone V, Mennucci B, Cossi M, Scalmani G, Rega N, Petersson GA, Nakatsuji H, Hada M, Ehara M, Toyota K, Fukuda R, Hasegawa J, Ishida M, Nakajima T, Honda Y, Kitao O, Nakai H, Klene M, Li X, Knox JE, Hratchian HP, Cross JB, Bakken V, Adamo C, Jaramillo J, Gomperts R, Stratmann RE, Yazyev O, Austin AJ, Cammi R, Pomelli C, Ochterski JW, Ayala PY, Morokuma K, Voth GA, P Salvador, Dannenberg JJ, Zakrzewski VG, Dapprich S, Daniels AD, Strain MC, Farkas O, Malick DK, Rabuck AD, 
Raghavachari K, Foresman JB, Ortiz JV, Cui Q, Baboul AG, Clifford S, Cioslowski J, Stefanov BB, Liu G, Liashenko A, Piskorz P, Komaromi I, Martin RL, Fox DJ, Keith T, Al-Laham MA, Peng CY, Nanayakkara A, Challacombe M, Gill PMW, Johnson B, Chen W, Wong MW, Gonzalez C, Pople JA, Gaussian 03, Revision E.01, Gaussian, Inc: Wallingford CT, 2004.

[24] Lee C, Yang W, Parr RG. Development of the Colle-Salvetti correlation-energy formula into a functional of the electron density. Phys Rev 1988; B37: 785.

[25] Becke AD. Density-functional thermochemistry. III. The role of exact exchange. J Chem Phys 1993; 98: 5648.

[26] Alacu IM, Zheng J, Zhao Y, Truhlar DG. Computational Thermochemistry: Scale Factor Databases and Scale Factors for Vibrational Frequencies Obtained from Electronic Model Chemistries. J Chem Theory Comput 2010; 6: 2872-2887.

[27] Scott AP, Random L. Harmonic Vibrational Frequencies: An Evaluation of Hartree-Fock, Møller-Plesset, Quadratic Configuration Interaction, Density Functional Theory, and Semiempirical Scale Factors. J Phys Chem 1996; 100: 16502-16513.

[28] Ditchfield R. Molecular Orbital Theory of Magnetic Shielding and Magnetic Susceptibility. J Chem Phys 1972; 56: 5688.

[29] Wolinski K, Hinton JF, Pulay P. Efficient implementation of the gauge-independent atomic orbital method for NMR chemical shift calculations. J Am Chem Soc 1990; 112: 8251-8260.

[30] Dincer M, Özdemir N, Cukurovali A, Yilmaz I, Buyukgungor O. "1-(3-Mesityl-3methylcyclobutyl)-2-(pyrrolidin-1-yl)ethan-1-one. Acta Cryst 2004; E60: o1523-o1524.

[31] Sen F, Dincer M, Cukurovali A, Yilmaz I. (Z)-1-(3-Mesityl-3-methylcyclobu-tyl)-2-(morpholin4-yl) ethanone oxime. Acta Cryst 2011; E67: o958-o959.

[32] Ozdemir N, Dincer M, Yilmaz I, Cukurovali A. 1-Methyl-1-phenyl-3-(phthalimidoacetyl) cyclobutane. Acta Cryst 2004; E60: o14-o16.

[33] Allen FH. The geometry of small rings VI: Geometrey and bonding in cyclobutane and cyclobutene. Acta Cryst 1984; B40: 64-72.

[34] Xu X.-X, You X.-Z, Sun Z.-F, Wang X, Liu H.-X. 2.2'-Azinodimethyldiphenol, $\mathrm{C}_{14} \mathrm{H}_{12} \mathrm{~N}_{2} \mathrm{O}_{2}$. Acta Cryst 1994; C50: 1169-1171.

[35] Sen F, Dincer M, Cukurovali A, Yilmaz I. 1,1'-Bis(3-methyl-3-phenylcyclobutyl)-2,2'-(azanediyl)diethanol. Acta Cryst 2012; E68: o1052.

[36] Ozdemir N, Dincer M, Cukurovali A, Buyukgungor O. "Experimental and theoretical investigation of the molecular and electronic structure of 5-(4-aminophenyl)-4-(3- methyl-3phenylcyclobutyl) thiazol-2-amine. J Mol Model 2009; 15: 1435-1445.

[37] Jian FF, Zhao PS, Bai ZS, Zhang L. Quantum Chemical Calculation Studies on 4-Phenyl-1(Propan-2-Ylidene)Thiosemicarbazide. Struct Chem 2005; 16: 635-639.

[38] Bellamy LJ. The Infrared Spectra of Complex Molecules, vol. 2, Chapman and Hall; London, 1980. 
[39] Sokrates G. Infrared Characteristic Group Frequencies, Wiley Intersciences Publication; New York, 1980.

[40] Dollish FR, Fateley WG, Bentley FF. Characteristic Raman Frequencies of Organic Compounds, John Wiley \& Sons; New York, 1997.

[41] Roeges NPG. A Guide to Complete Interpretation of Infrared Spectra of Organic Structures, Wiley; New York, 1994.

[42] Ozdemir N, Dincer M. Cukurovali. An experimental and theoretical approach to the molecular structure of 2-\{4-[3-(2,5-dimethylphenyl)-3-methylcyclobutyl]thiazol-2-yl\}isoindoline-1,3-dione A. J Mol Model 2010; 16: 291-302.

[43] Politzer P, Murray JS. The fundamental nature and role of the electrostatic potential in atoms and molecules. Theor Chem Acc 2002; 108: 134-142.

[44] Scrocco E, Tomasi J. Electronic Molecular Structure, Reactivity and Intermolecular Forces: An Euristic Interpretation by Means of Electrostatic Molecular Potentials Adv Quant Chem 1979; 11: 115-193.

[45] Luque FJ, Lopez JM, Orozco M. Perspective on "Electrostatic interactions of a solute with a continuum. A direct utilization of ab initio molecular potentials for the prevision of solvent effects. Theor Chem Acc 2000; 103: 343-345.

[46] Okulik N, Jubert AH. Theoretical Analysis of the Reactive Sites of Non-steroidal Antiinflammatory Drugs, Internet Electron. J Mol Des 2005; 4: 17-30.

[47] Politzer P, Laurence PR, Jayasuriya K, in: J. McKinney (Ed.), Structure Activity Correlation in Mechanism Studies and Predictive Toxicology, Special Issue of Environ Health Perspect 2005; 102: 61-191.

[48] Scrocco E, Tomasi J. The electrostatic molecular potential as a tool for the interpretation of molecular properties. Topics in Current Chemistry; Springer Berlin 1973; 7: 95-170.

[49] Politzer P, Truhlar DG. Chemical Applications of Atomic and Molecular Electrostatic Potentials, Plenum Press; New York 1981; 1-6.

[50] Fleming I. Frontier Orbitals and Organic Chemical Reactions, Wiley; London, 1973.

[51] O' Boyle NM, Tenderholt AL, Langer KM. cclib: a library for package-independent computational chemistry algorithms. J Comput Chem 2008; 29: 839-845.

[52] (a) Mulliken RS. Electronic Population Analysis on LCAO-MO Molecular Wave Functions. I. J Chem Phys 1955; 23: 1833,

(b) Mulliken RS, Electronic Population Analysis on LCAO-MO Molecular Wave Functions. I. J Chem Phys 1955; 23: 1841,

(c) Mulliken RS, Electronic Population Analysis on LCAO-MO Molecular Wave Functions. I. J Chem Phys 1955; 23: 2338,

(d) Mulliken RS, Electronic Population Analysis on LCAO-MO Molecular Wave Functions. I. J Chem Phys 1955; 23: 2343. 